\title{
Digestive System Hemangioma
}

National Cancer Institute

\section{Source}

National Cancer Institute. Digestive System Hemangioma. NCI Thesaurus. Code C7741.

A hemangioma arising from any part of the digestive system. 